\title{
Performance and Emissions of Mixed Ethanol-Biodiesel Calophyllum Inophyllum Fueled Diesel Engine
}

\author{
Rima Zidni Karimatan Nisak ${ }^{1}$, Nasrul Ilminnafik ${ }^{2}$, Salahuddin Junus ${ }^{3}$ \\ ${ }^{1-3}$ Department of Mechanical Engineering, Jember University, Indonesia
}

\begin{abstract}
This article evaluated the use of biodiesel from the Nyamplung seed oil (calophyllum inophyllum) and ethanol for petrodiesel mixture without modifying the diesel engine test instrument. The three tests were applied to each load on the test machine from 0 to $800 \mathrm{~W}$ with increments of $200 \mathrm{~W}$ at a constant engine speed of $2400 \mathrm{rpm}$. In this study, the percentage of biodiesel was 30\%, while the ethanol was $10 \%$ and $20 \%$, respectively. The percentage of petrodiesel decreased with the percentage of ethanol. From the analysis result of engine performance characteristics and exhaust emissions, it can be concluded that the addition of $20 \%$ ethanol and $30 \%$ biodiesel indicated the best engine performance characteristics with decreasing specific energy consumption up to $4.19 \%$ and the enhancement of effective thermal efficiency up to $1.60 \%$. Furthermore, preferable combustion quality also reduced carbon monoxide emissions up to $28.57 \%$ and hydrocarbon emissions up to $32.02 \%$.
\end{abstract}

Key words : Ethanol, Biodiesel, Nyamplung, Diesel Engine.

\section{INTRODUCTION}

The energy consumption is dominated by BBM (fuel oil) sourced from fossils (non-renewable energy) [1]. Indonesia Energy Outlook (2019) explains that the transportation sector is the largest sector in energy consumption (43\%) of the total national energy consumption. The fulfillment energy based on fuel oil has an impact on the production of crude oil deficit and condensate (natural gas liquids), so the energy supply based on new and renewable energy needs to be increased.

Biodiesel is a type of liquid biofuel used as an alternative to petrodiesel (petroleum diesel) mixed fuel. The biodiesel features are good lubrication, non-toxicity, high cetane number, no aromatics content, and can reduce exhaust emissions [2]. Biodiesel-base from vegetable or animal oils contains saturated free fatty acids that can increase kinematic viscosity, density, cloud point and pour point. Therefore, the use of these raw materials in the transportation sector is restricted [3]-[5].

Ethanol is an inexpensive oxygenate produced through the fermentation process of biomass raw materials [6] and used as a mixed fuel of diesel engines without modification [7]. The low viscosity and density of ethanol improve the spray characteristics and the mixed air-fuel process [6].

Paul et al., (2017) conducted research on the use of biodiesel and ethanol on the CI (compression ignition) engine performance with biodiesel from Malapari (pongamia pinnata) [9]. The concentration of biodiesel is $50 \%$ and ethanol is $5 \%$ which increased to $20 \%$ an increasing interval of $5 \%$. The results showed that the optimal engine performance is obtained by adding $15 \%$ ethanol pointed by an enhancement of BTE (brake thermal efficiency) as $21 \%$, a reduction of BSEC (brake specific energy consumption) as $4.61 \%$ and, a reduction of NOx (nitrogen oxide) and $\mathrm{HC}$ (hydrocarbon) exhaust emissions.

Based on the previous research, the augment of biodiesel and ethanol can improve diesel engine performance and reduce harmful exhaust emissions. This study aims to determine the diesel engines performance and exhaust emissions by biodiesel fuel Nyamplung seed oil (calophyllum inophyllum) and $99.5 \%$-purity ethanol.

\section{MATERIAL AND METHODS}

\subsection{Fuel Preparation}

Biodiesel is produced from Nyamplung seed oil (calophyllum inophyllum) by esterification and transesterification processes. The esterification process aims to reduce the free fatty acids value using methanol as a solvent and $\mathrm{H}_{2} \mathrm{SO}_{4}$ as a catalyst at $60^{\circ} \mathrm{C}$ for 120 minutes with a solvent-to-oil ratio of $22: 1 \mathrm{~mol} / \mathrm{mol}$ and a catalyst-to-oil ratio of $2 \% \mathrm{vol} / \mathrm{vol}$. The transesterification process was conducted with methanol and $\mathrm{KOH}$ as a catalyst at $60^{\circ} \mathrm{C}$ for 180 minutes with a solvent-to-oil ratio of $6: 1 \mathrm{~mol} / \mathrm{mol}$ and a catalyst-to-oil ratio of $1 \% \mathrm{~g} / \mathrm{g}$. The ethanol fuel with a purity of $99.5 \%$ was obtained from PT Energi Agro Nusantara, Mojokerto, East Java, Indonesia. Meanwhile, the petrodiesel fuel is obtained from PT Pertamina Tanjung Wangi, Ketapang, Banyuwangi, East Java, Indonesia.

Biodiesel as $30 \%$ and petrodiesel as 70\% (B30) mixed with ratio $\mathrm{vol} / \mathrm{vol}$. The ethanol concentration of $10 \%$ mixed with B30 becomes B3010. The ethanol concentration of 20\% mixed with B30 becomes B30E20. Each mixed fuel is observed for 24 hours to ensure mixed stability. 
Rima Zidni Karimatan Nisak et al., International Journal of Emerging Trends in Engineering Research, 9(8), August 2021, 1124 - 1128

\subsection{Fuel Characteristics}

Table 1. Physical chemistry of mixed biodiesel-ethanol fuel

\begin{tabular}{lccccc} 
& Viskosity & Density & $\begin{array}{c}\text { Caloric } \\
\text { value }\end{array}$ & $\begin{array}{c}\text { Cetane } \\
\text { number }\end{array}$ & Ref. \\
& & & & & \\
\cline { 2 - 4 } & $(\mathrm{cSt})$ & $\left(\mathrm{kg} / \mathrm{m}^{3}\right)$ & $(\mathrm{kJ} / \mathrm{kg})$ & & \\
\hline B20 & 2.8 & 853 & 43221 & - & {$[4]$} \\
B20E5 & 2.6 & 843 & 39761 & - & \\
B2.5E2.5 & 2.6 & 830 & 47389 & 57.2 & {$[10]$} \\
B5E5 & 2.6 & 830 & 46239 & 56.2 & \\
B10E5 & 1.6 & 808 & 42290 & - & \\
B10E10 & 1.4 & 808 & 41614 & - & {$[11]$} \\
B10E15 & 1.3 & 808 & 40032 & - & \\
B17E5 & 3.4 & 848 & 37040 & 55.0 & {$[12]$} \\
B49E10 & 3.2 & 854 & 35980 & 54.6 & \\
B20 & 3.7 & 843 & 43890 & - & {$[13]$} \\
B20E5 & 3.3 & 839 & 43120 & - & {$[13$} \\
\hline
\end{tabular}

Table 1. presented the physical chemistry of mixed biodiesel-ethanol fuel from various references. Ethanol affects the physical chemistry of the fuel. The enhancement of ethanol reduces the kinematic viscosity, density, calorific value, and cetane number of fuel, it is similar to [4], [10]-[13].

\subsection{Experimental Settings and Procedures}

This study used the MDX-170 Matsumoto diesel engine, single-cylinder, four-stroke, and natural air system. 1-phase Daiho SD-3 generator has functioned as a dynamometer. The data collection was conducted 3 times by connecting the rotor to the engine shaft. The stator is located opposite the rotor and connected to the casing. In the casing, an arm is installed where the end of the arm is a load cell (load measuring instrument). Allocating lights on the stator as $0-800 \mathrm{~W}$ or $0-100 \%$ with an increasing interval of $200 \mathrm{~W}$ at a constant engine speed of $2400 \mathrm{rpm}$. The braking force will be read on the load cell which is equal to the engine shaft rotational force (F). Figure 1. showed the scheme on the experimental setup.

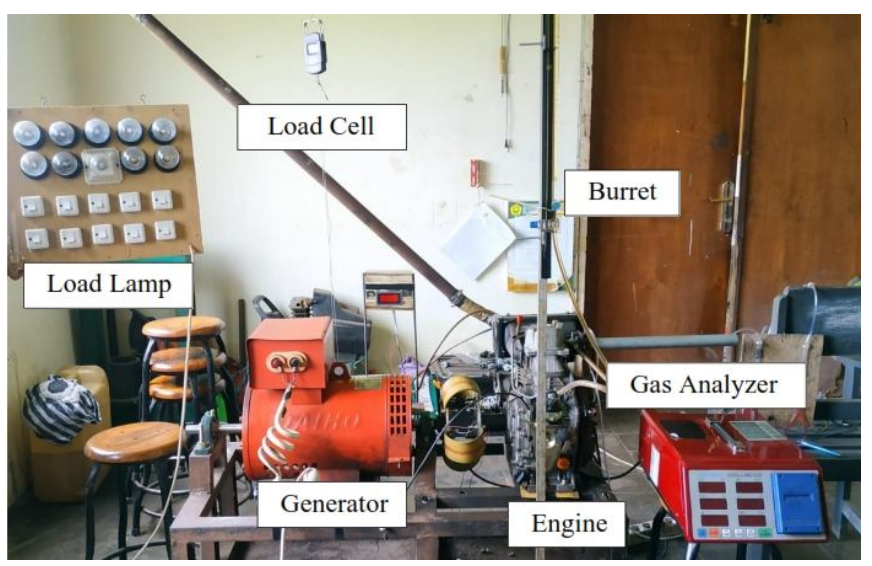

Figure 1. The scheme on the experimental setup

The gas analyzer HG-520 Hashbon is used to measure exhaust gas emissions of $\mathrm{CO}$ (carbon monoxide), $\mathrm{CO}_{2}$ (carbon dioxide), and HC (hydrocarbon) with the instrument accuracy of $0.01 \%, 0.1 \%$, and $0.01 \mathrm{ppm}$, respectively.

\section{RESULTS AND DISCUSSIONS}

3.1 The Effect of Biodiesel and Ethanol on Engine Performance

Parameters used to characterize diesel engine performance were specific energy consumption, effective thermal efficiency, and specific fuel consumption.

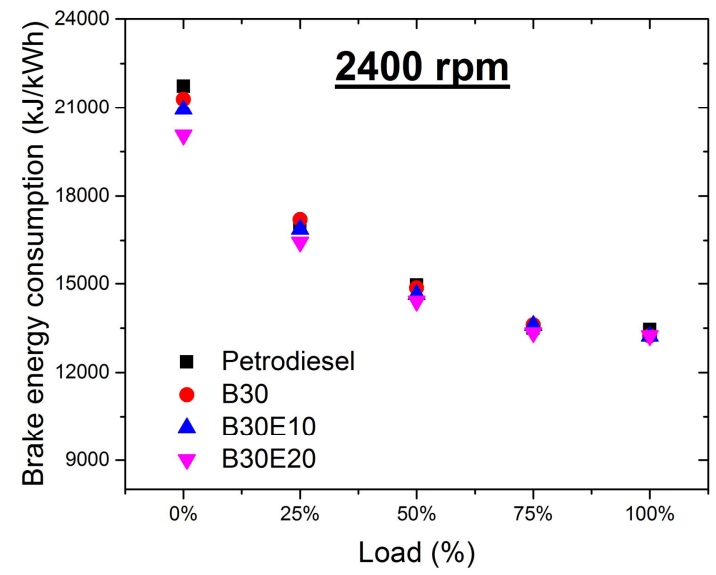

Figure 2. Brake specific energy consumption $(\mathrm{kJ} / \mathrm{kWh})$

Figure 2. showed the graph of brake specific energy consumption or BSEC $(\mathrm{kJ} / \mathrm{kWh})$. BSEC indicated the engine efficiency on the input of the energy fuel used by the engine during combustion [9]. The results of the mixed fuel tested on different load conditions showed that the augment of $20 \%$ ethanol (B30E20) was adequate to reduce BSEC than $\mathrm{B} 30 \mathrm{E} 10, \mathrm{~B} 30$, and petrodiesel fuels. In the minimum load, the B30E20 reduces BSEC by $4.19 \%$. It was lower than petrodiesel. This result was similar to Işik, (2020) [14]. The consistent reduction of BSEC indicated the preferable utilization of chemical energy becomes useful energy [9]. The high oxygen in ethanol plays a role in the combustion phase and easy the release of higher fuel energy during oxidation [14], [15].

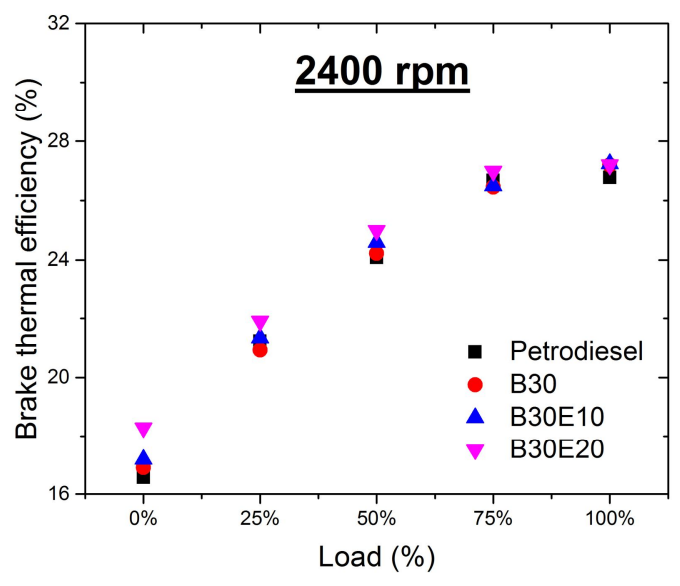

Figure 3. Brake thermal effective (\%) 
Figure 3. showed a graph of the brake thermal effective or BTE (\%). BTE is used to evaluate the engine quality in converting the thermal energy of the fuel to mechanical energy [9]. The results of the mixed fuel tested at different load conditions revealed that B30E20 fuel had a higher BTE than other fuels, such as B30E10, B30, and petrodiesel. In the maximum load, the B30E20 increased BTE by $1.60 \%$ higher than petrodiesel fuel. This result is similar to Bhurat et al., (2019) [16].

The high percentage of ethanol had an effect on reducing the fuel viscosity, thus this condition allowed preferable fuel injection. The improvement of injection quality simplifies the fuel atomization. It allowed the large and small chain hydrocarbons from biodiesel and petrodiesel to bond rapidly into the smaller elements during combustion [9]. The oxygen in ethanol also participated in the fuel combustion process, thus the BTE B30E20 is detected to be higher than other mixed fuels [17].

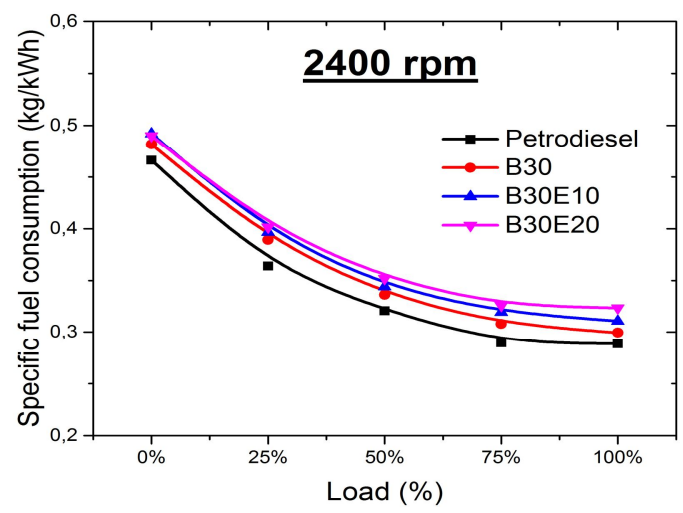

Figure 4. Specific fuel consumption $(\mathrm{kg} / \mathrm{kWh})$

Figure 4. showed a graph of specific fuel consumption or SFC $(\mathrm{kg} / \mathrm{kWh})$. The SFC is the fuel consumption rate used by the engine to produce force. The results of the mixed fuel tested at different load conditions showed an enhancement of SFC and ethanol concentration. A high concentration of ethanol reduced the heating value and density of the mixed fuel [18]. Lowering the heating value reduced the fuel energy discharge, thus it required a high rate of fuel consumption to obtain the same force [15].

The results of the mixed fuel tested at different load conditions showed that B30E20 had a higher SFC than other fuels, such as B30E10, B30, and petrodiesel. In the maximum load, the B30E20 increased SFC as $12.08 \%$ higher than petrodiesel fuel. These results were similar to Bhurat et al., (2019) [16].

\subsection{The Effect of Biodiesel and Ethanol on Exhaust Emissions}

Parameters used to characterize exhaust emissions of diesel engines were carbon monoxide, carbon dioxide, and hydrocarbon..

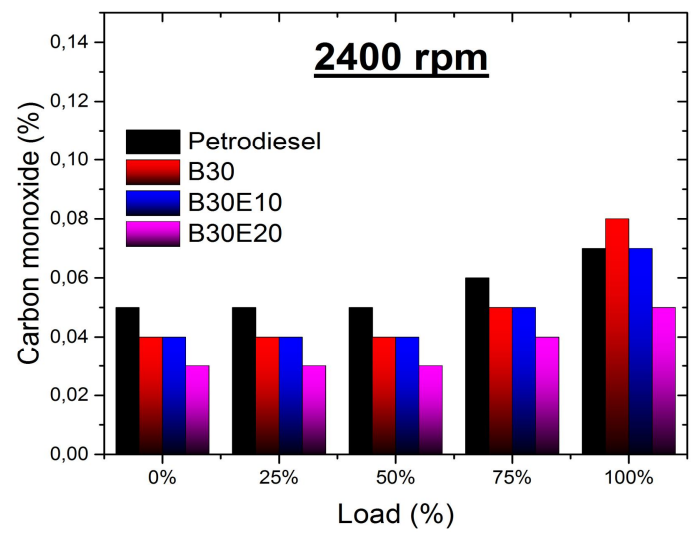

Figure 5. Carbon monoxide (\%)

Figure 5. showed a graph of carbon monoxide or CO $(\%)$ exhaust emissions. The results of the mixed fuel tested on different load conditions showed that the $\mathrm{CO}$ emission of B30E20 fuel was lower than B30E10, B30, and petrodiesel fuels. It was similar to Paul et al., (2017) who stated that in the maximum load, B30E20 fuel reduces $\mathrm{CO}$ emissions as $28.57 \%$ lower than petrodiesel fuel [9]. The rate of $\mathrm{CO}$ emission depended on the air-fuel ratio. The enhancement of oxygen and the augment of ethanol assisted to increase the oxygen ratio of the mixed fuel in the rich fuel areas, thus leading to complete combustion [19].

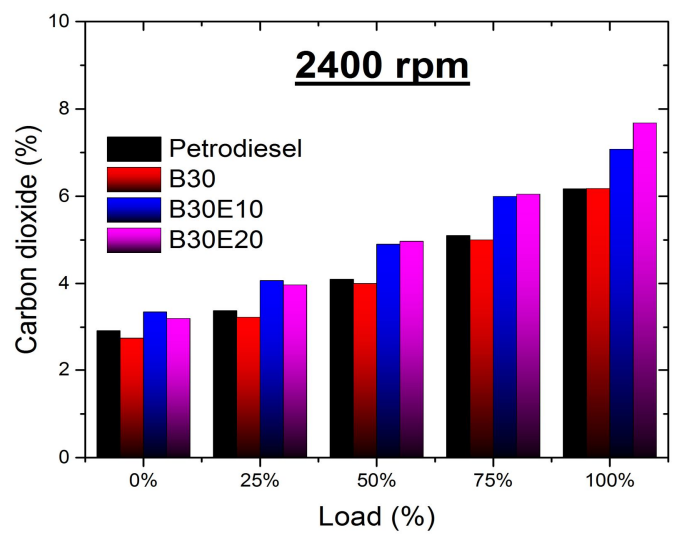

Figure 6. Carbon dioxide (\%)

Figure 6. showed a graph of carbon dioxide or $\mathrm{CO}_{2}(\%)$ exhaust emissions. This graph showed that the augment of ethanol in the mixed fuel constantly increased $\mathrm{CO}_{2}$ emissions. The $\mathrm{CO}_{2}$ emissions increased because ethanol released ' $\mathrm{OH}$ ' during oxidation. The ' $\mathrm{OH}$ ' radicals supported the $\mathrm{CO}$ emissions oxidation to $\mathrm{CO}_{2}$ emissions [9]. The results of the mixed fuel tested at different load conditions showed that B30E20 had the highest $\mathrm{CO}_{2}$ emissions, followed by B30E10, B30, and petrodiesel fuels. This result similar to Işik et al., (2020) who mention that in the maximum load, B30E20 fuel increased $\mathrm{CO}_{2}$ emissions as $24.47 \%$ higher than petrodiesel fuel [14]. 


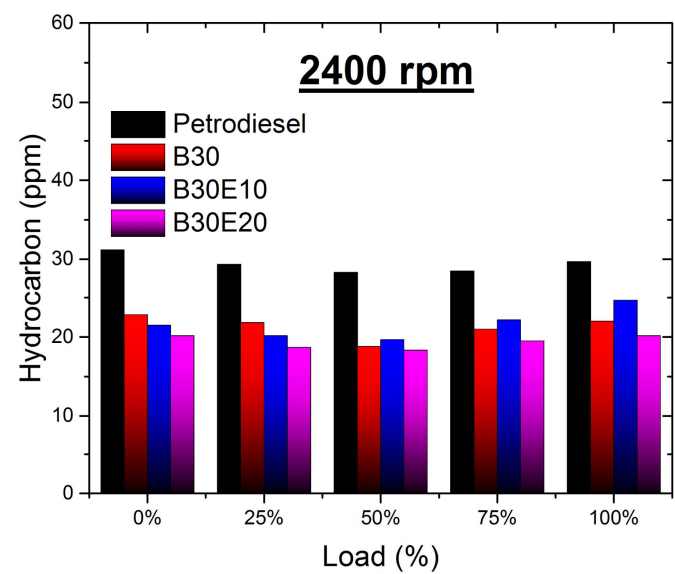

Figure 7. Hydrocarbon (ppm)

Figure 7. showed a graph of hydrocarbon or HC exhaust gas emissions (ppm). The results of the mixed fuel tested on different load conditions showed that the $\mathrm{HC}$ emission of B30E20 fuel was lower than B30E10, B30, and petrodiesel fuels. This result was similar to Rizwanul Fattah et al., (2014) who stated that in the maximum load, B30E20 fuel reduced $\mathrm{HC}$ emissions by $32.02 \%$ less than petrodiesel fuel [20]. The unburned $\mathrm{HC}$ emission was related to combustion quality [18]. The oxygen content in ethanol contributed to the fuel combustion process in the complete combustion [19], so it was competent to reduce $\mathrm{HC}$ emissions [20].

\section{CONCLUSION}

In this study, the experimental research was conducted on diesel engine to explore the biodiesel and ethanol effects on the performance and exhaust emissions of diesel engine. The biodiesel percentage was still constant at $30 \%$, while the ethanol had increased from $10 \%$ to $20 \%$. The petrodiesel percentage decreased continuously with the ethanol percentage. Based on the results, it can be concluded that the augment of $20 \%$ ethanol and $30 \%$ biodiesel (B30E20) can improve engine performance, such as reducing BSEC and increasing BTE better than petrodiesel. However, the SFC was higher than petrodiesel. In terms of exhaust emissions, the $\mathrm{B} 30 \mathrm{E} 20$ reduced $\mathrm{CO}$ and $\mathrm{HC}$ emissions but increased the $\mathrm{CO}_{2}$ emissions.

\section{REFERENCES}

[1] I. Kholiq, "Pemanfaatan energi alternatif sebagai energi terbarukan untuk mendukung subtitusi BBM," Jurnal IPTEK, vol. 19, no. 2, p. 17, 2015.

[2] S. N. Gebremariam and J. M. Marchetti, "Economics of biodiesel production: Review," Energy Convers. Manag., vol. 168, pp. 74-84, Jul. 2018, doi: 10.1016/j.enconman.2018.05.002.

[3] A. E. Atabani and A. da S. César, "Calophyllum inophyllum L. - A prospective non-edible biodiesel feedstock. Study of biodiesel production, properties, fatty acid composition, blending and engine performance," Renew. Sustain. Energy Rev., vol. 37, pp. 644-655, Sep. 2014, doi: 10.1016/j.rser.2014.05.037.

[4] S. Madiwale, A. Karthikeyan, and V. Bhojwani, "Properties investigation and performance analysis of a diesel engine fuelled with Jatropha, Soybean, Palm and Cottonseed biodiesel using Ethanol as an additive," Mater. Today Proc., vol. 5, no. 1, pp. 657-664, 2018, doi: 10.1016/j.matpr.2017.11.130.

[5] Punithkumar Y. K, M. Khaiser, B. S. .Mahesh, and Y. K. K J, "Performance Analysis of Biodiesel Blends of Surahonne and Dairy Scum Waste on I.C Engine," Int. J. Emerg. Technol. Eng. Res. IJETER, vol. 6, no. 2, p. 5, Feb. 2018.

[6] M. S. M. Zaharin, N. R. Abdullah, G. Najafi, H. Sharudin, and T. Yusaf, "Effects of physicochemical properties of biodiesel fuel blends with alcohol on diesel engine performance and exhaust emissions: A review," Renew. Sustain. Energy Rev., vol. 79, pp. 475-493, Nov. 2017, doi: 10.1016/j.rser.2017.05.035.

[7] M. Kumar, A. Kerihuel, J. Bellettre, and M. Tazerout, "Ethanol animal fat emulsions as a diesel engine fuel Part 2: Engine test analysis," Fuel, vol. 85, no. 17-18, pp. 2646-2652, Dec. 2006, doi: 10.1016/j.fuel.2006.05.023.

[8] A. Paul, R. Panua, and D. Debroy, "An experimental study of combustion, performance, exergy and emission characteristics of a CI engine fueled by Diesel-ethanol-biodiesel blends," Energy, vol. 141, pp. 839-852, Dec. 2017, doi: 10.1016/j.energy.2017.09.137.

[9] A. Paul, R. Panua, and D. Debroy, "An experimental study of combustion, performance, exergy and emission characteristics of a CI engine fueled by

Diesel-ethanol-biodiesel blends," Energy, vol. 141, pp. 839-852, Dec. 2017, doi: 10.1016/j.energy.2017.09.137.

[10] F. Aydın and H. Ögüt, "Effects of using ethanol-biodiesel-diesel fuel in single cylinder diesel engine to engine performance and emissions," Renew. Energy, vol. 103, pp. 688-694, Apr. 2017, doi: 10.1016/j.renene.2016.10.083.

[11] H. V. Srikanth, S. Godiganur, B. Manne, and S. B. Kumar, "Niger seed oil biodiesel as an emulsifier in diesel-ethanol blends for compression ignition engine," Renew. Energy, p. S0960148120310867, Jul. 2020, doi: 10.1016/j.renene.2020.07.010.

[12] S. M. Krishna, P. Abdul Salam, M. Tongroon, and N. Chollacoop, "Performance and emission assessment of optimally blended biodiesel-diesel-ethanol in diesel engine generator," Appl. Therm. Eng., vol. 155, pp. 525-533, Jun. 2019, doi: 10.1016/j.applthermaleng.2019.04.012.

[13] H. G. How, H. H. Masjuki, M. A. Kalam, and Y. H. Teoh, "Engine Performance, Emission and Combustion Characteristics of a Common-rail Diesel Engine Fuelled with Bioethanol as a Fuel Additive in Coconut Oil 
Biodiesel Blends," Energy Procedia, vol. 61, pp. 1655-1659, 2014, doi: 10.1016/j.egypro.2014.12.185.

[14] M. Z. Işik, "Comparative experimental investigation on the effects of heavy alcohols- safflower biodiesel blends on combustion, performance and emissions in a power generator diesel engine," p. 38, Sep. 2020.

[15] J. B. Heywood, Internal combustion engine fundamentals. New York: McGraw-Hill, 1988.

[16] S. S. Bhurat, S. Pandey, V. Chintala, and P. S. Ranjit, "Experimental study on performance and emissions characteristics of single cylinder diesel engine with ethanol and biodiesel blended fuels with diesel," Mater. Today Proc., vol. 17, pp. 220-226, 2019, doi: 10.1016/j.matpr.2019.06.422.

[17] M. Ußner, "Biofuels today and tomorrow: effects of fuel composition on exhaust gas emissions," p. 7, 2009.

[18] A. de Oliveira, A. M. de Morais, O. S. Valente, and J. R. Sodré, "Combustion characteristics, performance and emissions from a diesel power generator fuelled by B7-ethanol blends," Fuel Process. Technol., p. 7, 2015.

[19] S. M. Krishna, P. Abdul Salam, M. Tongroon, and N. Chollacoop, "Performance and emission assessment of optimally blended biodiesel-diesel-ethanol in diesel engine generator," Appl. Therm. Eng., vol. 155, pp. 525-533, Jun. 2019, doi: 10.1016/j.applthermaleng.2019.04.012.

[20] I. M. Rizwanul Fattah, M. A. Kalam, H. H. Masjuki, and M. A. Wakil, "Biodiesel production, characterization, engine performance, and emission characteristics of Malaysian Alexandrian laurel oil," RSC Adv, vol. 4, no. 34, pp. 17787-17796, 2014, doi: 10.1039/C3RA47954D. 